1 Microbial Electrolysis Cells for production of methane

2 from $\mathrm{CO}_{2}$ : long-term performance and perspectives

3 Mieke C. A. A. Van Eerten-Jansen, Annemiek Ter Heijne*, Cees J. N. Buisman, Hubertus V. M.

Hamelers

Sub-Department of Environmental Technology, Wageningen University, Bornse Weilanden 9,

P.O. Box 17, 6700 AA Wageningen, The Netherlands

8 RECEIVED DATE

9

10

11

12

13

14

15

16 * Corresponding author phone: +31 317 483447; fax: +31 317 482108; e-mail:

17 Annemiek.terHeijne@wur.nl 
2 A methane producing Microbial Electrolysis Cell (MEC) is a technology to convert $\mathrm{CO}_{2}$ into

3 methane, using electricity as an energy source and microorganisms as the catalyst. A methane

4 producing MEC provides the possibility to increase the fuel yield per hectare of land area, when the

$5 \mathrm{CO}_{2}$ produced in biofuel production processes is converted to additional fuel methane. Besides

6 increasing fuel yield per hectare of land area, this also results in more efficient use of land area,

7 water, and nutrients. In this research, the performance of a methane producing MEC was studied for

8188 days in a flat plate MEC design. Methane production rate and energy efficiency of the methane

9 producing $\mathrm{MEC}$ were investigated with time to elucidate the main bottlenecks limiting system

10 performance. Using water as the electron donor at the anode during continuous operation, methane

11 production rate was $0.006 \mathrm{~m}^{3} / \mathrm{m}^{3}$ per day at a cathode potential of $-0.55 \mathrm{~V}$ vs. NHE with a coulombic

12 efficiency of 23.1\%. External electrical energy input was $73.5 \mathrm{kWh} / \mathrm{m}^{3}$ methane, resulting in a

13 voltage efficiency of $13.4 \%$. Consequently, overall energy efficiency was $3.1 \%$. The maximum

14 achieved energy efficiency was obtained in a yield test and was 51.3\%. Analysis of internal

15 resistance showed that on the short-term, cathode and anode losses were dominant, but with time,

16 also $\mathrm{pH}$ gradient and transport losses became more important. The results obtained in this study are

17 used to discuss the possible contribution of methane producing MECs to increase in fuel yield per

18 hectare of land area.

19

20 KEY WORDS

21 Microbial Electrolysis Cell, $\mathrm{CO}_{2}$ reduction, methane, biomass efficiency, land use 
There is a societal need for the production of fuels from alternative, renewable energy sources to

3 substitute fossil fuels. Organic material (biomass) is an attractive feedstock for the production of biofuels, as it is often locally available, it could contribute to reducing greenhouse gas emissions when produced and utilized in a sustainable way, and biomass can be easily stored [1]. The current biofuel debate, however, shows that it is questionable whether sufficient biomass can be produced in a sustainable way to cover all the world's fuel needs [2, 3]. To achieve a higher and more sustainable

8 biofuel production, it is therefore of importance that the fuel yield per hectare of the available land area should be increased, while water and nutrients should be used as efficiently as possible [4, 5].

The amount of biomass used for energy production has increased considerably from 648 Mtoe in

111973 to 1179 Mtoe in 2007 [6]. In the conversion of biomass into biofuel, e.g. fermentation of sugars

12 into ethanol or anaerobic digestion of acetate into methane, most of the oxygen atoms present in

13 organic material need to be removed to produce a high energy density fuel. These oxygen atoms are 14 removed in the form of $\mathrm{CO}_{2}$ [7]. For example, in case of fermentation of sugars into ethanol, for each mole of ethanol produced, 1 mole of $\mathrm{CO}_{2}$ is formed. Similarly, in case of anaerobic digestion of acetate into methane, for each mole of methane produced, 1 mole of $\mathrm{CO}_{2}$ is formed. In this process

17 of removing oxygen atoms in the form of $\mathrm{CO}_{2}$ part of the carbon present in biomass is lost [7]. If the

18 by-product $\mathrm{CO}_{2}$ is converted into additional fuel, this would increase the fuel yield per hectare of

19 land area. This increases not only the fuel yield land use efficiency, but also the efficiency of use of 20 nutrients and water. This research therefore investigates whether a Microbial Electrolysis Cell 21 (MEC) is a suitable technology to convert $\mathrm{CO}_{2}$ to additional fuel.

An MEC is a novel technology that uses renewable electricity as the energy source for the

23 production of fuels and chemicals, such as hydrogen [8], ethanol [9], and hydrogen peroxide [10]. A

24 recently developed application for MECs is to produce methane from $\mathrm{CO}_{2}$ using microorganisms as 25 the catalyst, with input of electrical energy [11]. A methane producing MEC consists of two 26 electrodes, anode and cathode, separated by a membrane. The membrane is essential to produce pure 27 products [12]. At the anode, an oxidation reaction takes place, e.g. the oxidation of acetate or water, 
1 yielding $\mathrm{CO}_{2}$ or $\mathrm{O}_{2}$ respectively, and protons and electrons. Electrons are released to the anode and

2 flow through an external electrical circuit to the cathode, while protons and cations migrate through

3 the membrane to the cathode to maintain electroneutrality. At the cathode, the protons and electrons

4 are used to produce methane. The reaction at the cathode is catalyzed by electrochemically active

5 microorganisms, i.e. hydrogenotrophic methanogens [11], and the cathode is therefore called a

6 biocathode. In a methane producing MEC, the overall reaction is thermodynamically not favorable

7 and needs electrical energy to drive the reaction [13].

8 Hydrogenotrophic methanogens can catalyze methane production from $\mathrm{CO}_{2}$ in an $\mathrm{MEC}$ via two 9 mechanisms: (i) direct extracellular electron transfer (eq. 1), i.e. the electrons are directly taken up 10 from the electrode and used to reduce the $\mathrm{CO}_{2}$ to methane,

$$
\mathrm{CO}_{2}+8 \mathrm{H}^{+}+8 \mathrm{e}^{-} \rightarrow \mathrm{CH}_{4}+2 \mathrm{H}_{2} \mathrm{O} \quad\left(\mathrm{E}_{\text {cat }}=-0.24 \mathrm{~V} \text { vs. NHE [11] }\right)
$$

13 All reported potentials are standard potentials under biological relevant conditions at $\mathrm{pH} 7$ and $25^{\circ} \mathrm{C}$.

15 and (ii) indirect extracellular electron transfer (eq. 2 and 3), i.e. with intermediate production of 16 hydrogen [11, 14]. In this mechanism first hydrogen is produced at the cathode either 17 electrochemically or bio-electrochemically (eq. 2).

$192 \mathrm{H}^{+}+2 \mathrm{e}^{-} \rightarrow \mathrm{H}_{2}$

$$
\left(E_{\text {cat }}=-0.41 \mathrm{~V}\right. \text { vs. NHE [15]) }
$$

21 This hydrogen is used together with $\mathrm{CO}_{2}$ to produce methane (eq. 3).

$23 \quad \mathrm{CO}_{2}+4 \mathrm{H}_{2} \rightarrow \mathrm{CH}_{4}+2 \mathrm{H}_{2} \mathrm{O}$

25 Methane production via direct extracellular electron transfer is considered the most energy26 efficient process, as the standard potential of hydrogen production via indirect extracellular electron 27 transfer $\left(\mathrm{E}_{\mathrm{cat}}=-0.41 \mathrm{~V}\right.$ vs. $\left.\mathrm{NHE}\right)$ is lower than of methane production via direct extracellular 
electron transfer $\left(E_{c a t}=-0.24 \mathrm{~V}\right.$ vs. NHE). The protons and electrons needed for the reduction

2 reaction at the cathode are produced by oxidizing water at the anode (eq. 4).

3

$4 \quad 4 \mathrm{H}_{2} \mathrm{O} \rightarrow 2 \mathrm{O}_{2}+8 \mathrm{H}^{+}+8 \mathrm{e}^{-}$

$$
\left(\mathrm{E}_{\mathrm{an}}=0.81 \mathrm{~V}\right. \text { vs. NHE [13]) }
$$

The overall process is the production of methane from $\mathrm{CO}_{2}$ and water (eq. 5).

$8 \mathrm{CO}_{2}+2 \mathrm{H}_{2} \mathrm{O} \rightarrow \mathrm{CH}_{4}+2 \mathrm{O}_{2}$

$$
\left(\mathrm{E}_{\text {cell }}=-1.05 \text { to }-1.22 \mathrm{~V}\right. \text { vs. NHE) }
$$

The minimum thermodynamic energy input required is thus achieved when employing direct

11 reduction of $\mathrm{CO}_{2}$ to methane, and is $32.7 \mathrm{MJ}$ electrical energy per $\mathrm{m}^{3}$ of methane $\left(9.1 \mathrm{kWh} / \mathrm{m}^{3}\right.$ 12 methane) under biologically relevant conditions ( $\mathrm{pH} 7$ and $25^{\circ} \mathrm{C}$ ).

13 This paper studies whether a methane producing MEC is a suitable technology for increasing the 14 fuel yield per hectare of land area. Previous studies on methane producing MECs focused on the mechanism of methane production and showed that direct reduction of $\mathrm{CO}_{2}$ to methane coupled to water oxidation is feasible with an additional energy input on top of the thermodynamic energy input

$17[11,14]$. However, the different types of energy losses occurring in the MEC that lead to this 18 additional energy input were not extensively studied. Insight in these energy losses is essential to 19 improve the performance of methane producing MECs, and consequently to increase the fuel yield 20 per hectare of land area. This study therefore investigated the nature and extent of energy losses in a 21 methane producing MEC and their effects on MEC energy efficiency and methane production rates.

22 The oxygen produced at the anode could negatively affect the performance of methane producing 23 MECs. The oxygen might diffuse to the cathode [16] and could lead to parasitic reactions either via 24 direct reduction to water at the cathode or via oxidizing the methane produced. Oxygen is also 25 known to inhibit hydrogenotrophic methanogens [17] and might decrease the methane production 26 rate. To understand a possible negative role of oxygen, the methane producing MEC was first 27 operated for 83 days using hexacyanoferrate(II) oxidation at the anode and subsequently for 105 
1 days using water oxidation at the anode. The performance of the biocathode in both periods was

2 analyzed using polarization curves and yield tests. The overall performance of the methane

3 producing MEC was determined by analyzing the resistances of the different elements of the

4 methane producing MEC, i.e. anode, cathode, membrane, and electrolyte, and by analyzing the

5 overall energy efficiency. The results obtained in this study were finally used to discuss the possible

6 contribution of methane producing MECs to increase in fuel yield per hectare of land area.

$8 \quad$ Materials and methods

$9 \quad$ Experimental set-up

10 The experiment was performed in the same electrochemical cell as described in Sleutels et al. [18]

11 with a total volume of $0.56 \mathrm{~L}$ using a cation exchange membrane $(0.7 \mathrm{~mm}$, Ralex CM, Mega a.s.,

12 Czech Republic). The anode was made of platinum coated $\left(50 \mathrm{~g} / \mathrm{m}^{2}\right)$ titanium mesh (projected 13 surface area $250 \mathrm{~cm}^{2}$, thickness $1 \mathrm{~mm}$, specific surface area $1.7 \mathrm{~m}^{2} / \mathrm{m}^{2}$ - Magneto Special Anodes 14 BV, The Netherlands). The cathode was made of graphite felt (projected surface area $0.025 \mathrm{~m}^{2}$, 15 thickness 3 mm - FMI Composites Ltd., Scotland). Both the anode and cathode compartment were 16 equipped with an Ag/AgCl $3 \mathrm{M} \mathrm{KCl}$ reference electrode (+0.205 V vs. NHE; ProSense QiS, The 17 Netherlands). The electrochemical cell was connected to a PC via a Fieldpoint FP-AI-110 module 18 (National Instruments, United States) and every 60 seconds cell voltage, current, and cathode and 19 anode potential were recorded using LabVIEW 7.1 (National Instruments, United States). A 20 luminescent dissolved oxygen probe (LDO10101, Hach, USA) was installed in the catholyte, and 21 every 30 minutes dissolved oxygen in the catholyte was measured. The system was operated in a 22 temperature controlled chamber at $30^{\circ} \mathrm{C}$.

Electrolytes and microorganisms

25 Oxygen, product of water oxidation at the anode, can possibly affect methanogens at the cathode 26 [17]. To prevent oxygen to affect biofilm development at the cathode at the start of the experiment, 27 hexacyanoferrate(II) was oxidized at the anode. Because hexacyanoferrate(II) is not sustainable as it 

is not self-regenerating [13], it was changed to water oxidation on day 83. At start, anolyte consisted of $100 \mathrm{mM}$ potassium hexacyanoferrate(II) and was circulated at $1.5 \mathrm{~mL} / \mathrm{s}$. The anolyte was

3 refreshed regularly to avoid depletion of electron donor. The anolyte was changed to demineralized water containing $20 \mathrm{mM}$ potassium phosphate buffer on day 83. The catholyte influent consisted of a $20 \mathrm{mM}$ potassium phosphate buffer, macronutrients $\left(280 \mathrm{mg} / \mathrm{L} \mathrm{NH} \mathrm{N}_{4} \mathrm{Cl}, 5.7 \mathrm{mg} / \mathrm{L} \mathrm{CaCl}, 10 \mathrm{mg} / \mathrm{L}\right.$ $\mathrm{MgSO}_{4} \cdot 7 \mathrm{H}_{2} \mathrm{O}, 90 \mathrm{mg} / \mathrm{L} \mathrm{MgCl}_{2} \cdot 6 \mathrm{H}_{2} \mathrm{O}$ ), and $1 \mathrm{~mL} / \mathrm{L}$ of a micronutrients and vitamin solution same as [19]. The catholyte influent was supplemented with $5 \mathrm{~g} / \mathrm{L} \mathrm{NaHCO}_{3}$ as carbon source, as at operating $\mathrm{pH} 7 \mathrm{CO}_{2}$ is mainly present as $\mathrm{HCO}_{3}{ }^{-}$, and circulated at $1.5 \mathrm{~mL} / \mathrm{s}$. The catholyte was continuously refreshed at a rate of $0.1 \mathrm{~mL} / \mathrm{min}$ (Stepdos 03RC, KNF, Germany). 5 gram of anaerobic sludge, obtained from an UASB treating distillery wastewater (Nedalco, The Netherlands), was used as

11 inoculum and the electrochemical cell was flushed with pure nitrogen (>99.9992\%) for 30 minutes 12 before applying a cell voltage. $\mathrm{pH}$ of the catholyte was controlled at $\mathrm{pH} 7 \pm 0.1$ through a $\mathrm{pH}$ 13 controller (Liquisis M CPM 253, Endress+Hauser, Switzerland) using $1 \mathrm{M} \mathrm{HCl.}$

MEC operation

During long-term MEC operation there is a risk on malfunctioning of the reference electrodes in the electrochemical cell. To prevent damage to the methane producing biocathode as a result of

19 The electrochemical cell was connected to a power supply (MCP94, Bank Elektronik, Germany).

20 Cell voltage was adjusted to obtain the desired cathode potential, when cathode potential deviated

$21>20 \mathrm{mV}$ from the desired cathode potential.

22 The experiment was started using a biocathode from an already running MEC using

23 hexacyanoferrate(II) oxidation at the anode. This biocathode had a current density of $0.3 \mathrm{~A} / \mathrm{m}^{2}$ and 24 was operated at an $\mathrm{E}_{\mathrm{cat}}$ of $-0.8 \mathrm{~V}$ vs. NHE. At the start of the experiment (day 0 ) this biocathode was 25 inoculated to make sure that sufficient biomass was present. From day 0 to day 83, with 26 hexacyanoferrate(II) as the anolyte, the cathode potential was controlled at $-0.7 \mathrm{~V}$ vs. NHE. After 27 switching the anolyte to water (day 83 to 177), the cathode potential was $-0.55 \mathrm{~V}$ vs. NHE. This 
potential was higher than with hexacyanoferrate(II), and is the result of the maximum range in applied cell voltage of the potentiostat, which was limited to $-2 \mathrm{~V}$. This range limited the cathode

3 potential as the anode potential required for water oxidation was higher than the anode potential

4 required for hexacyanoferrate(II) oxidation. On day 188, the experiment was finished due to

5 leakages in the MEC.

\section{Polarization tests}

8 Polarization tests were made using an IviumStat potentiostat with a Peripheral Port Expander

9 (Ivium Technologies, Eindhoven, The Netherlands). The applied cathode potential was decreased

10 from $-0.4 \mathrm{~V}$ to $-1.0 \mathrm{~V}$ with steps of $0.1 \mathrm{~V}$, each step lasting 10 minutes, using hexacyanoferrate(II)

11 oxidation at the anode. When using water oxidation at the anode, the cell voltage was controlled

12 instead of cathode potential. In this case, the applied cell voltage was decreased from $-1.0 \mathrm{~V}$ to -2.0

$13 \mathrm{~V}$ with steps of $0.1 \mathrm{~V}$, each step lasting 10 minutes, and cathode potential was continuously recorded

14 versus a reference electrode. This resulted in a cathode potential at highest $-0.21 \mathrm{~V}$ vs. NHE and at

15 lowest $-0.78 \mathrm{~V}$ vs. NHE using water oxidation at the anode. Current was recorded each second and 16 the last ten data points at each cathode potential were averaged and plotted in the polarization curve.

18 Gas analysis

19 Gas composition of the cathode gas phase was measured with two different gas chromatographs,

20 same as [20], to measure all gasses present. Gas production was measured with a gas flow meter 21 (Milligascounter®, Ritter, Germany).

22 Methane production rate was calculated from the measured gas production and gas composition 23 using the mass balance equation described by [21]:

$$
V_{C H_{4, t}}=V_{C H_{4, t-1}}+\left(V_{T, t}-V_{T, t-1}\right) \cdot \frac{C_{C H_{4, t}}+C_{C H_{4, t-1}}}{2}+V_{c a t} \cdot\left(c_{C H_{4, t}}-C_{C H_{4, t-1}}\right)
$$

25 with $\mathrm{V}_{\mathrm{CH} 4, \mathrm{t}}$ and $\mathrm{V}_{\mathrm{CH} 4, \mathrm{t}-1}$ the cumulative methane gas production $\left(\mathrm{L} \mathrm{CH}_{4}\right)$ on sample time $\mathrm{t}$ and 26 previous sample time $\mathrm{t}-1$, respectively, $\mathrm{V}_{\mathrm{T}, \mathrm{t}}$ and $\mathrm{V}_{\mathrm{T}, \mathrm{t}-1}$ the total gas production measured with a gas 27 flow meter (L) on sample time $t$ and previous sample time $t-1$, respectively, $\mathrm{C}_{\mathrm{CH} 4, \mathrm{t}}$ and $\mathrm{C}_{\mathrm{CH} 4, \mathrm{t}-1}$ the 
1 measured methane fractions in the cathode gas phase (-) on sample time $t$ and previous sample time

$2 \mathrm{t}-1$, respectively, and $\mathrm{V}_{\text {cat }}$ the cathode headspace volume $(0.7 \mathrm{~L})$.

3

$4 \quad$ Yield tests

5 To compare performance of the methane producing biocathode between the two anolytes

6 hexacyanoferrate(II) and water, a methane yield tests of 8h was performed on day 70 (13 days before

7 switching anolytes), and day 101 (18 days after switching anolytes). Before the yield test was

8 started, the cathode compartment was flushed with pure nitrogen (>99.9992\%) for 30 minutes.

9 During the yield test, the cathode potential was controlled at $-0.7 \mathrm{~V}$ vs. NHE using an IviumStat

10 potentiostat. Catholyte was continuously refreshed as described for continuous operation, and at the

11 start and end of the yield test the cathode gas phase was analyzed for methane as described.

13 Energy efficiency

14 The two most important parameters to describe performance of the MEC are methane production 15 rate and energy efficiency. Methane production rate was determined as described in yield tests.

16 Energy efficiency (eq. 7) of a methane producing MEC is the product of coulombic efficiency (eq. 8)

17 and voltage efficiency (eq. 9) [12].

18

$$
\eta_{\text {energy }}=\eta_{C E} \cdot \eta_{\text {voltage }}=\frac{-\Delta G_{C_{4}} \cdot V_{C_{4}}}{V_{m} \cdot E_{\text {cell }} \cdot \int_{t=0}^{t} I d t}
$$

19 Coulombic efficiency $\left(\eta_{\mathrm{CE}}, \%\right)$, the efficiency of capturing the electrons from the electric current 20 in methane, was calculated via

$$
\eta_{C E}=\frac{V_{C H_{4}} \cdot F \cdot n}{V_{m} \cdot \int_{t=0}^{t} I d t}
$$

22 with $V_{\mathrm{CH}_{4}}$ the cumulative methane gas production $\left(\mathrm{m}^{3} \mathrm{CH}_{4}\right), \mathrm{F}$ the Faradays constant (96485

$23 \mathrm{C} /$ mole $\mathrm{e}^{-}$), $\mathrm{n}$ the moles of electrons per mole of methane (8 mole $\mathrm{e}^{-} / \mathrm{mole}^{\mathrm{CH}} \mathrm{H}_{4}$ ), $\mathrm{V}_{\mathrm{m}}$ the molar 24 volume $\left(0.0252 \mathrm{~m}^{3} / \mathrm{mole}\right)$, I the current (A), and the time (s). 
Voltage efficiency, the amount of external electrical energy that ends up in methane, was

2 calculated via the Gibb’s free energy of oxidation of methane over the electrical energy input of the

3 MEC

4 membrane using Fick’s law

$$
J_{O_{2}}=D_{O_{2}} \cdot \frac{\left(c_{O_{2, a n}}-c_{O_{2, c a t}}\right)}{\delta}
$$

\section{Oxygen diffusion through membrane}

$$
\eta_{\text {voltage }}=\frac{E_{\text {emf }}}{E_{\text {cell }}}=\frac{-\Delta G_{C H_{4}}}{E_{\text {cell }} \cdot n \cdot F}
$$

with $E_{\text {emf }}$ the so called reversible energy loss $(V)$, i.e. the electrical energy converted into chemical energy in the form of methane, $E_{\text {cell }}$ the energy input of the MEC, i.e. the applied cell voltage (V), and $\Delta \mathrm{G}_{\mathrm{CH} 4}$ the Gibb’s free energy of oxidation of methane (890.4 kJ/mole $\mathrm{CH}_{4}$ [22]).

To improve the performance of the methane producing MEC, factors that affect the energy efficiency should be identified. Therefore, the effect of oxygen diffusion through the membrane on MEC performance was calculated, and an internal resistance analysis of the methane producing MEC was performed as described hereafter.

The coulombic efficiency reflects to which extent other electron consuming reactions, so called parasitic reactions, than the preferred $\mathrm{CO}_{2}$ reduction reaction take place in the electrochemical cell. Parasitic oxidation occurs when oxygen produced at the anode diffuses to the cathode, where it oxidizes methane and/or hydrogen to $\mathrm{CO}_{2}$ and/or water. This results in a decrease in methane production rate and a lower coulombic efficiency (smaller part of the electrons ending up in methane). Parasitic reduction occurs when oxygen is directly reduced to water at the cathode. The contribution of parasitic oxidation or reduction to coulombic efficiency can be estimated by calculating the oxygen diffusion flux ( $\mathrm{J}_{\mathrm{O} 2}$ in mole $\mathrm{O}_{2} / \mathrm{m}^{2}$ per second) over the cation exchange

with $\mathrm{D}_{\mathrm{O} 2}$ the diffusion coefficient of oxygen determined for a CMI-7000 cation exchange membrane (Membrane International Inc., USA) $\left(4.3 \cdot 10^{-10} \mathrm{~m}^{2} / \mathrm{s}\right)$ [16], $\mathrm{C}_{\mathrm{O} 2 \text {,an }}$ and $\mathrm{C}_{\mathrm{O} 2 \text {,cat }}$ the dissolved oxygen concentration at the anode and cathode (mole $\mathrm{O}_{2} / \mathrm{m}^{3}$ ), respectively, and $\delta$ the thickness of the 
1 membrane as supplied by the manufacturer $\left(0.7 \cdot 10^{-3} \mathrm{~m}\right)$. The oxygen diffusion flux is inversely

2 proportional to the thickness of the membrane. The estimated rate of methane oxidation ( $\mathrm{r}_{\mathrm{CH} 4, \mathrm{ox}}$ in $\mathrm{m}^{3}$

$3 \mathrm{CH}_{4} / \mathrm{m}^{3}$ per day) due to this flux of oxygen is

$$
r_{\mathrm{CH}_{4,0 x}}=\frac{J_{\mathrm{O}_{2}} \cdot A \cdot V_{m} \cdot t}{2 \cdot V_{\text {reactor }}}
$$

with A the membrane surface area $\left(0.025 \mathrm{~m}^{2}\right)$, $\mathrm{t}$ the time $(\mathrm{d}), \mathrm{V}_{\text {reactor }}$ the total reactor volume $(0.56$

L), and taking into account that 2 moles of oxygen are consumed per mole methane.

\section{Internal resistance analysis}

9 The applied cell voltage consists of a thermodynamically calculated cell voltage needed to produce

10 methane under biologically relevant conditions, the reversible energy loss $\mathrm{E}_{\mathrm{emf}}$, and internal energy

11 losses, the so called irreversible energy losses [18]. Irreversible energy losses, energy lost as a result

12 of the resistances of different parts of the MEC, consist of the $\mathrm{pH}$ gradient over the membrane

$13\left(E_{\Delta p H}\right)$, cathode overpotential $\left(\eta_{\text {cat }}\right)$, anode overpotential $\left(\eta_{\mathrm{an}}\right)$, ionic losses $\left(E_{\text {ionic }}\right)$, and transport

14 losses $\left(\mathrm{E}_{\mathrm{T}}\right)$, that were calculated according to [18]

$$
E_{\text {cell }}=E_{\text {emf }}-E_{\Delta p H}-\eta_{\text {cat }}-\eta_{a n}-E_{\text {ionic }}-E_{T}
$$

16 with $E_{e m f}=E_{c a t}-E_{a n}(V)$. Cathode $\left(E_{c a t}\right)$ and anode $\left(E_{a n}\right)$ potential were calculated using the Nernst

17 equation under experimentally relevant conditions $\left(E_{\mathrm{Fe}(I I)}^{0}=0.361 \mathrm{~V}\right.$ vs. $\mathrm{NHE}, \mathrm{T}=303 \mathrm{~K},\left[\mathrm{Fe}(\mathrm{CN})_{6}{ }^{4-}\right.$

18 ] is assumed on average to be equal to $\left[\mathrm{Fe}(\mathrm{CN})_{6}{ }^{3-}\right][13], E_{\mathrm{H}_{2} \mathrm{O}}^{0}=1.229 \mathrm{~V}$ vs. NHE, $\mathrm{pO}_{2}=0.28 \cdot 10^{5} \mathrm{~Pa}$

19 (average measured liquid dissolved oxygen concentration cathode was $12.4 \mathrm{mg} \mathrm{O} / \mathrm{L}$ (day 83-177)),

$20 E_{\text {cat }}^{0}=0.169 \mathrm{~V}$ vs. NHE, $\mathrm{pCH}_{4}=0.075 \cdot 10^{5} \mathrm{~Pa}$ (pressure cathode compartment was 1.005 bar with an

21 average measured methane concentration of 8.78\% (day 0-188)), $\left[\mathrm{HCO}_{3}^{-}\right]=0.06 \mathrm{M},\left[\mathrm{H}^{+}\right]=10^{-7} \mathrm{M}$ ).

22 As anolyte and catholyte $\mathrm{pH}$ changed with time, these were included in the irreversible energy losses

23 calculations.

24

$$
E_{a n, F e(I I)}=E_{F e(I I)}^{0}-\frac{R \cdot T}{F} \cdot \ln \left(\frac{\left[\mathrm{Fe}(\mathrm{CN})_{6}{ }^{4-}\right]}{\left[\mathrm{Fe}(\mathrm{CN})_{6}{ }^{3-}\right]}\right)=0.36 \mathrm{~V} \text { vs. NHE }
$$




$$
E_{a n, \mathrm{H}_{2} \mathrm{O}}=E_{\mathrm{H}_{2} \mathrm{O}}^{0}-\frac{R \cdot T}{4 \cdot F} \cdot \ln \left(\frac{1}{p O_{2} \cdot\left[H^{+}\right]^{4}}\right)=0.87 \mathrm{~V} \text { vs. NHE }
$$

$$
E_{\text {cat }}=E_{c a t}^{0}-\frac{R \cdot T}{8 \cdot F} \cdot \ln \left(\frac{\left[\mathrm{CH}_{4}\right]_{\text {sat }}}{\left[\mathrm{HCO}_{3}^{-}\right] \cdot\left[H^{+}\right]^{9}}\right)=-0.34 V \text { vs. NHE }
$$

$3 \quad$ Ionic and transport losses were calculated from all other potential losses using equation 12.

4 Parameters measured in time to calculate potential losses were anode and cathode potential,

5 catholyte and anolyte $\mathrm{pH}$, and cell voltage. At a constant applied cell voltage, the current density that

6 is produced by MECs depends on the internal resistance of the MEC. Partial resistances $\left(\mathrm{R}_{\mathrm{i}}\right.$ in $\left.\Omega \cdot \mathrm{m}^{2}\right)$

7 were calculated by dividing the calculated potential loss by the current density, and total internal

8 resistance was the sum of the partial resistances [18].

9 For analysis of internal resistance during continuous operation, six representative periods were

10 chosen. These six periods were:

11 1) at the start of the experiment using hexacyanoferrate(II) oxidation (days 2-6, indicated as 'start $\left.12 \mathrm{Fe}^{\prime}\right)$,

13 2) in the middle of stable operation using hexacyanoferrate(II) oxidation (days 50-57, indicated as 14 'middle Fe'),

15 3) before switching anolytes (day 83, indicated as 'end Fe'),

16 4) after switching anolytes (day 83, indicated as 'start water'),

17 5) in the middle of stable operation using water oxidation (days 125-132, indicated as 'middle 18 water'), and

19 6) at the end of the experiment using water oxidation (days 167-176, indicated as 'end water'). 


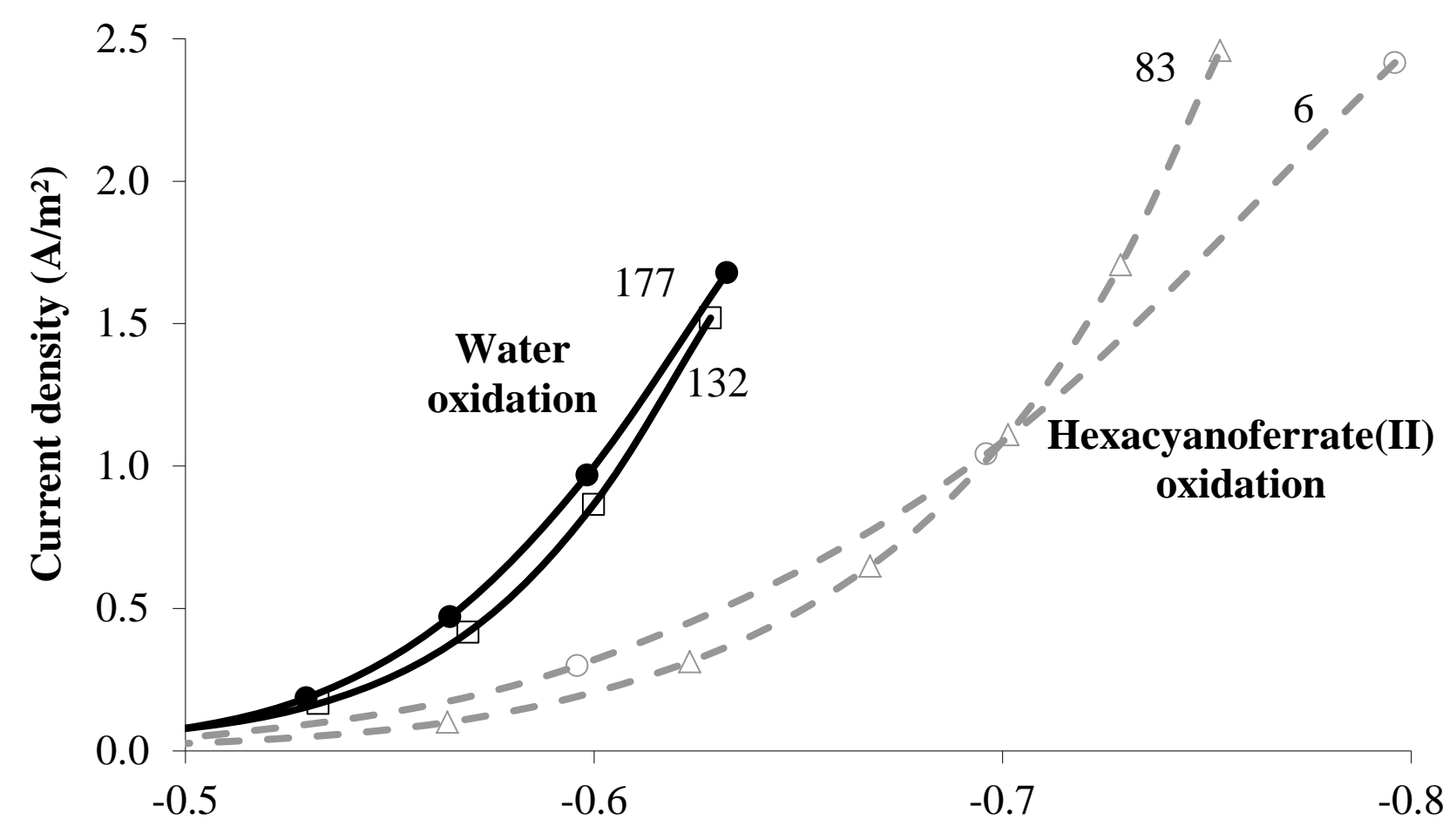

Cathode potential (V vs. NHE)

3 Figure 1. Polarization tests give insight in the performance of a methane producing biocathode in

4 time (operation day indicated in figure) using hexacyanoferrate(II) (grey dashed line) or water (black

5 solid line) oxidation at the anode.

$7 \quad$ Biocathode performance

8 Polarization tests are a useful tool to give insight in the development of the methane producing

9 biocathode with time. A higher current density at the same cathode potential indicates an increase in

10 performance. When using hexacyanoferrate (day 0-83) at the anode, during continuous operation

11 cathode potential was controlled at $-0.7 \mathrm{~V}$ vs. NHE, and current density was on average $0.78 \pm 0.20$

$12 \mathrm{~A} / \mathrm{m}^{2}$. The polarization curves as shown in Figure 1 show that the biocathode had similar

13 performance on days 6 and 83, indicating stable performance. The current density obtained in the

14 polarization curves at $-0.7 \mathrm{~V}$ vs. NHE is well within the range obtained during continuous operation.

15 After changing the anode reaction to water oxidation and increasing the cathode potential to $-0.55 \mathrm{~V}$

16 vs. NHE during continuous operation, current density was on average $0.25 \pm 0.04 \mathrm{~A} / \mathrm{m}^{2}$. Similar to

17 using hexacyanoferrate(II) oxidation at the anode, the polarization curves show that the biocathode 

had similar performance on days 132 and 177, indicating stable performance, and the current density obtained in the polarization curves at $-0.55 \mathrm{~V}$ vs. NHE is in line with the current density obtained

3 during continuous operation.

Figure 1 also shows that at the same cathode potential the biocathode performed better when using water oxidation compared to hexacyanoferrate(II) oxidation. The higher current density using water oxidation compared to hexacyanoferrate(II) oxidation could be the result of oxygen diffusion over the membrane resulting in parasitic reactions at the cathode, or the result of better performance of the biomass on the biocathode. Presence of oxygen at the cathode could lead to increased current production through direct oxygen reduction at the cathode. Whether parasitic reactions at the cathode are a plausible explanation for the better performance using water oxidation can be verified by calculating the oxygen flux over the cation exchange membrane (eq. 10 and 11). Dissolved oxygen concentration at the anode was on average $0.95 \mathrm{mg} / \mathrm{L}$ using hexacyanoferrate(II) oxidation, and 12.4 $\mathrm{mg} / \mathrm{L}$ using water oxidation, while dissolved oxygen concentration at the cathode was always 0 $\mathrm{mg} / \mathrm{L}$. This leads to an oxygen flux over the membrane of $1.8 \cdot 10^{-8}$ mole $\mathrm{O}_{2} / \mathrm{m}^{2}$ per second using hexacyanoferrate(II) oxidation, and $2.4 \cdot 10^{-7}$ mole $\mathrm{O}_{2} / \mathrm{m}^{2}$ per second using water oxidation. This flux of oxygen can consume electrons at a rate of $0.007 \mathrm{~A} / \mathrm{m}^{2}$ using hexacyanoferrate(II) oxidation, and $0.09 \mathrm{~A} / \mathrm{m}^{2}$ using water oxidation. This is equal to $0.6 \%$ of the measured current density at cathode potential $-0.7 \mathrm{~V}$ vs. NHE during the polarization test using hexacyanoferrate(II) oxidation and $37 \%$ of the measured current density at cathode potential $-0.55 \mathrm{~V}$ vs. NHE during the polarization test using water oxidation (Figure 1). These calculations show that oxygen diffusion over the membrane can explain part of the higher current density using water oxidation.

After correction for the additional current density caused by possible oxygen diffusion over the membrane, current density using water oxidation was still higher than when using hexacyanoferrate(II) oxidation (Figure 1). This suggests that the higher controlled cathode potential during continuous operation also lead to an increased current density. Using water oxidation, during continuous operation cathode potential was $-0.55 \mathrm{~V}$ vs. NHE, while during hexacyanoferrate(II) oxidation the cathode potential was $-0.7 \mathrm{~V}$ vs. NHE. The cathode potential of $-0.55 \mathrm{~V}$ vs. NHE was 
higher than used in previous studies, where potentials below $-0.7 \mathrm{~V}$ vs. NHE were investigated [11, $14,22,23]$. At this high cathode potential, direct $\mathrm{CO}_{2}$ reduction to methane is energetically more

3 favorable than $\mathrm{CO}_{2}$ reduction via hydrogen: eq. 1 and 2 show a higher potential for direct $\mathrm{CO}_{2}$ reduction compared to $\mathrm{CO}_{2}$ reduction via hydrogen, meaning that at $-0.55 \mathrm{~V}$ vs. NHE more energy is to be gained by the microorganisms via direct reduction of $\mathrm{CO}_{2}$. Previous study indeed revealed that at cathode potentials higher than $-0.75 \mathrm{~V}$ vs. NHE, methane was mainly produced via direct $\mathrm{CO}_{2}$ reduction, while at lower cathode potentials methane can also be produced indirectly via hydrogen [14]. In this study, at a cathode potential of $-0.55 \mathrm{~V}$ vs. NHE, direct reduction of $\mathrm{CO}_{2}$ was the most likely process, although we did not further investigate the mechanisms.

To further study the performance of the biocathode when using water oxidation at the anode

11 compared to hexacyanoferrate(II) oxidation, yield tests were performed, in which the cathode

12 potential was controlled at the same value of $-0.7 \mathrm{~V}$ vs. NHE. This was done on day 70 (13 days

13 before switching anolytes) and day 101 (18 days after switching anolytes). Table 1 shows that during

14 the yield test, the current density was $40 \%$ higher when using water oxidation compared to hexacyanoferrate(II) oxidation. This is in agreement to what was found during polarization tests (Figure 1). Methane production rate was 30\% higher when using water oxidation compared to

17 hexacyanoferrate(II) oxidation, and this was confirmed by the slightly lower coulombic efficiency

18 for water oxidation compared to hexacyanoferrate(II) oxidation in the yield tests. The coulombic

19 efficiency of hexacyanoferrate(II) oxidation in the yield test being higher than $100 \%$ could be a

20 result of biomass degradation and oxidation or storage of electrons in the microorganisms [24]. The

21 better performance of the biocathode when using water oxidation could also be a result of the lower

22 applied cathode potential in the yield test (-0.7 V vs. NHE) compared to the potential at which the

23 biofilm was acclimatized during continuous operation (-0.55 V vs. NHE). This change in cathode 24 potential could have affected the functioning of the biocathode.

25 The polarization curves and yield tests reveal that oxygen via parasitic reactions decreases the coulombic efficiency of the biocathode, however, it has no obvious negative effect on the methane 27 production rate. This might be explained by the fact that the oxygen reacts away either via direct 
1 reduction to water at the cathode or via oxidizing the methane produced, and therefore cannot affect

2 the methanogens present at the biocathode.

3

4 Long-term current generation and methane production in flat plate MEC

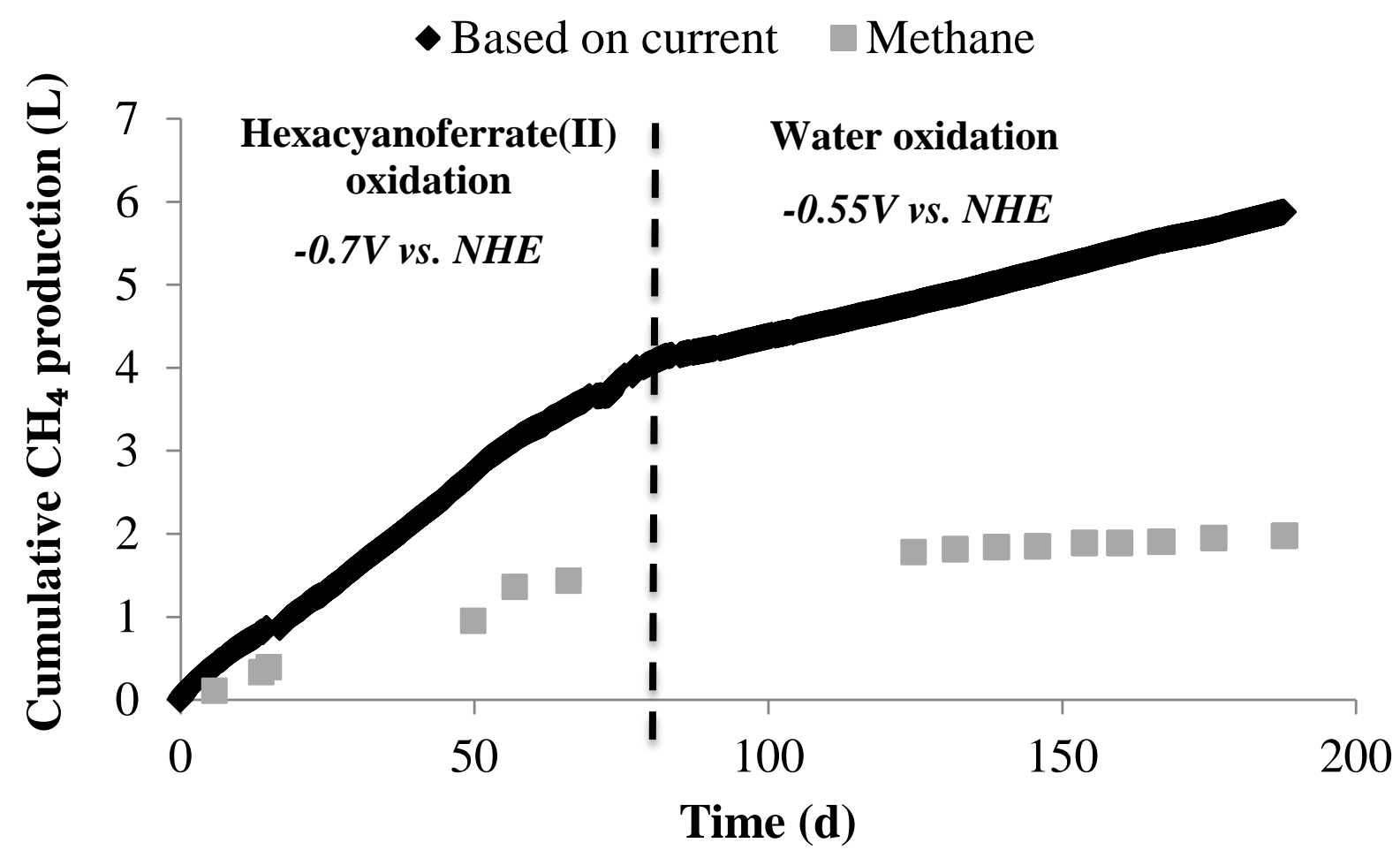

6 Figure 2. Cumulative methane production with time. The black diamonds indicate methane 7 production calculated from the current, while the grey squares indicate measured methane 8 production. Anolyte was changed from hexacyanoferrate(II) to water on day 83, as indicated by the 9 dashed line.

11 Current and methane were produced continuously in the flat plate MEC for 188 days (Figure 2). 12 When using hexacyanoferrate (day 0-83), cathode potential was controlled at $-0.7 \mathrm{~V}$ vs. NHE, and 13 current density ranged between $0.4 \mathrm{~A} / \mathrm{m}^{2}$ and $2.5 \mathrm{~A} / \mathrm{m}^{2}$, being on average $0.78 \pm 0.20 \mathrm{~A} / \mathrm{m}^{2}$. Methane 14 production ranged between $0.01-0.10 \mathrm{~m}^{3} \mathrm{CH}_{4} / \mathrm{m}^{3}$ per day, being on average $0.05 \pm 0.03 \mathrm{~m}^{3} \mathrm{CH}_{4} / \mathrm{m}^{3}$ 15 per day. After changing the anode reaction to water oxidation and increasing the cathode potential to $-0.55 \mathrm{~V}$ vs. NHE, current density decreased and ranged between $0.2 \mathrm{~A} / \mathrm{m}^{2}$ and $0.6 \mathrm{~A} / \mathrm{m}^{2}$ (day 8317 188), being on average $0.25 \pm 0.04 \mathrm{~A} / \mathrm{m}^{2}$. Methane production ranged between $3 \cdot 10^{-4}-0.025 \mathrm{~m}^{3}$ 
$1 \mathrm{CH}_{4} / \mathrm{m}^{3}$ per day, being on average $0.006 \pm 0.008 \mathrm{~m}^{3} \mathrm{CH}_{4} / \mathrm{m}^{3}$ per day. This decrease in gas production

2 rate when switching the anolyte from hexacyanoferrate(II) to water is in line with the lower current

3 density (Figure 2).

4 Methane production rate was on average a factor 8 higher using hexacyanoferrate(II) as electron

5 donor compared to water during continuous operation (Table 1). Part of the explanation for the lower

6 methane production rate when using water oxidation is the higher cathode potential and

7 consequently the lower current density, however, this cannot be the only explanation, as the current

8 density was only a factor 3-4 lower. Parasitic reactions that consume electrons will also lead to a

9 lower methane production rate. These parasitic reactions are reflected in the coulombic efficiency,

10 which was about a factor 1.5-4 lower when using water oxidation compared to hexacyanoferrate(II)

11 oxidation during continuous operation (Table 1). Whether parasitic reactions are a plausible

12 explanation for the lower coulombic efficiency can be verified by calculating the oxygen diffusion

13 flux over the cation exchange membrane. Average dissolved oxygen concentration at the anode was

$1412.3 \mathrm{mg} / \mathrm{L}$ using water oxidation, while dissolved oxygen concentration was always $0 \mathrm{mg} / \mathrm{L}$ at the

15 cathode. This leads to an oxygen flux over the membrane of $2.4 \cdot 10^{-7}$ mole $\mathrm{O}_{2} / \mathrm{m}^{2}$ per second. This

16 flux of oxygen can oxidize methane at a rate of $0.012 \mathrm{~m}^{3} \mathrm{CH}_{4} / \mathrm{m}^{3}$ per day. If we calculate the

17 expected methane production rate using the measured methane production rate in Table 1, and taking

18 into account the methane lost due to oxidation by oxygen, then the methane production rate using

19 water oxidation was $0.005+0.012=0.017 \mathrm{~m}^{3} \mathrm{CH}_{4} / \mathrm{m}^{3}$ per day (middle water) and $0.006+0.012=$

$200.018 \mathrm{~m}^{3} \mathrm{CH}_{4} / \mathrm{m}^{3}$ per day (end water). This would result in a maximum coulombic efficiency of

$2157.8 \%$ (middle water) and 67.5\% (end water), which is comparable to the coulombic efficiency for

22 hexacyanoferrate(II) oxidation. These calculations show that parasitic reactions can explain part of

23 the differences in coulombic efficiency between both anolytes.

24 Parasitic reactions alone, however, cannot explain why coulombic efficiency is considerably lower

25 than $100 \%$ for both anolytes during continuous operation. It is believed that part of the methane is

26 lost due to diffusion from the cathode to the anode, similar to hydrogen losses in MECs [15, 25], and

27 therefore less methane is measured in the cathode gas phase than expected from the measured 
current. The coulombic efficiency can likely be improved by using a membrane that is less permeable for gases. This results in less methane diffusion from the cathode to the anode, and less oxygen diffusion from the anode to cathode, and consequently in less parasitic reactions.

Methane production rates reported for methane producing bio-electrochemical systems using water oxidation are $0.012-0.015 \mathrm{~m}^{3} \mathrm{CH}_{4} / \mathrm{m}^{3}$ per day for two-compartment MECs at cathode potentials between $-0.8 \mathrm{~V}$ and $-0.9 \mathrm{~V}$ vs. NHE $[11,14]$. The methane production rates during continuous operation using hexacyanoferrate(II) oxidation, $0.033-0.071 \mathrm{~m}^{3} \mathrm{CH}_{4} / \mathrm{m}^{3}$ per day, were higher than previously reported methane production rates. Methane production rates during continuous operation

9 using water oxidation were somewhat lower, 0.005-0.006 $\mathrm{m}^{3} \mathrm{CH}_{4} / \mathrm{m}^{3}$ per day, however, this is 10 expected as the results are obtained at a cathode potential of $>0.25 \mathrm{~V}$ higher than used in other 11 studies.

Voltage efficiency and energy efficiency

14 During continuous operation using hexacyanoferrate(II) oxidation at the anode, the energy input was $15.4 \mathrm{kWh} / \mathrm{m}^{3}$ methane (start Fe; based on $\mathrm{E}_{\text {cell }}=-1.21 \mathrm{~V}$ ) and $31.6 \mathrm{kWh} / \mathrm{m}^{3}$ methane (middle Fe; based on $E_{\text {cell }}=-1.23 \mathrm{~V}$ ) (Table 1). Using water oxidation at the anode, the energy input was 97.2

$17 \mathrm{kWh} / \mathrm{m}^{3}$ methane (middle water; based on $\mathrm{E}_{\text {cell }}=-1.99 \mathrm{~V}$ ) and $73.5 \mathrm{kWh} / \mathrm{m}^{3}$ methane (end water; 18 based on $\mathrm{E}_{\text {cell }}=-1.99 \mathrm{~V}$ ) (Table 1). Gibb’s free energy of methane oxidation is $9.8 \mathrm{kWh} / \mathrm{m}^{3}$ methane 19 [22], so voltage efficiency was 63.7\% (start Fe) and 31.1\% (middle Fe) using hexacyanoferrate(II) 20 oxidation, and $10.1 \%$ (middle water) and $13.4 \%$ (end water) using water oxidation.

21 Energy efficiency (eq. 7) is the product of coulombic efficiency (eq. 8) and voltage efficiency (eq. 22 9) [12]. The energy efficiency was 42.6\% (start Fe) and $10.3 \%$ (middle $\mathrm{Fe}$ ) using 23 hexacyanoferrate(II) oxidation, and 1.8\% (middle water) and 3.1\% (end water) using water oxidation 24 (Table 1).

25 It should be noted that the energy efficiency using hexacyanoferrate(II) oxidation at the anode does not include the energy required for regeneration of hexacyanoferrate(II), which is essential for 27 hexacyanoferrate(II) to be a sustainable electron donor for use in practical applications [13]. The 
energy efficiency using hexacyanoferrate(II) oxidation at the anode, however, reveals the potential

2 performance of a methane producing biocathode using an efficient anode, and is useful to study the

3 effect of oxygen diffusion over the membrane on the performance of a methane producing MEC.

$4 \quad$ The yield tests show the maximum achieved voltage efficiency and energy efficiency. The energy

5 input in a yield test using hexacyanoferrate(II) oxidation was $16.6 \mathrm{kWh} / \mathrm{m}^{3}$ methane (day 70),

6 leading to a voltage efficiency of 59.3\% and an energy efficiency of 62.0\% (Table 1). The energy

7 input in a yield test using water oxidation was $18.2 \mathrm{kWh} / \mathrm{m}^{3}$ methane (day 101), leading to a voltage

8 efficiency of 53.9\% and an energy efficiency of 51.3\% (Table 1).

10 Identifying sources of irreversible energy losses

11 To study how energy efficiency can be improved, analysis of irreversible energy losses during

12 continuous operation of the methane producing MEC is essential. At a constant applied cell voltage,

13 the current density that is produced by MECs depends on the internal resistance of the MEC [18].

14 Therefore, partial resistances were calculated to identify which processes contributed most to the 15 total internal resistance of the MEC. These partial resistances represent cathode losses, anode losses, 16 losses due to the $\mathrm{pH}$ gradient over the membrane, and transport \& ionic losses.

17 Figure 3 shows an increase in total internal resistance with time for both anolytes. This causes a 18 decrease in current density with time. Current density decreased from $1.15 \mathrm{~A} / \mathrm{m}^{2}$ to $0.30 \mathrm{~A} / \mathrm{m}^{2}$ (from 19 start $\mathrm{Fe}$ to end $\mathrm{Fe}$ ) using hexacyanoferrate(II) oxidation, and from $0.30 \mathrm{~A} / \mathrm{m}^{2}$ to $0.25 \mathrm{~A} / \mathrm{m}^{2}$ (from 20 start water to end water) using water oxidation. From Figure 3, also two main effects can be seen: (i)

21 in case of hexacyanoferrate(II) oxidation, the total internal resistance was considerably lower than

22 with water oxidation, and was mainly caused by the cathode, and (ii) in case of water oxidation, in

23 the beginning anode and cathode contributed most to the total internal resistance, while $\mathrm{pH}$ and 24 transport \& ionic losses increased with time. 
- Total $\quad$ Cathode $=$ Anode $>\Delta \mathrm{pH} \quad$ II Transport and ionic

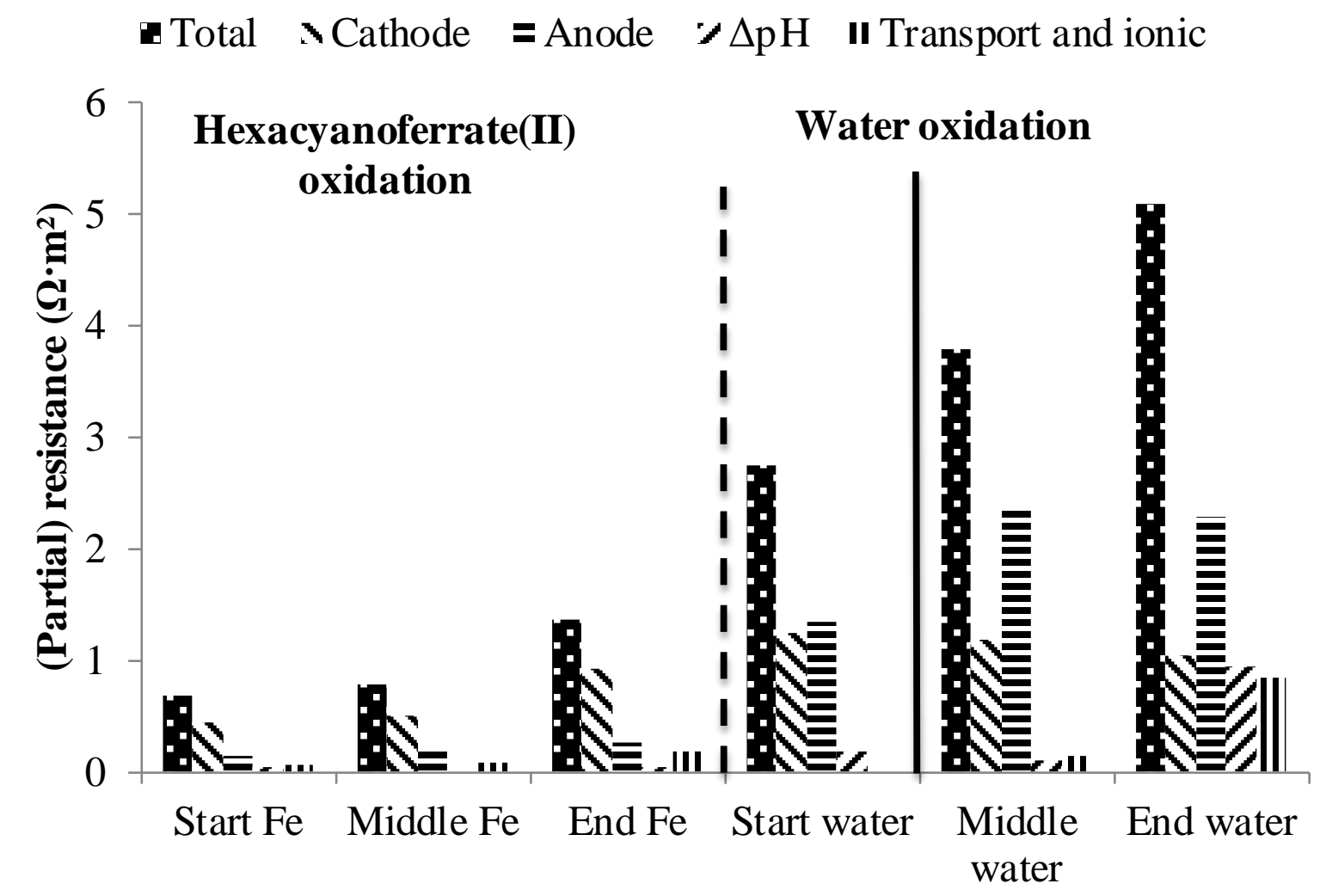

2 Figure 3. Total internal resistance, and partial resistances were measured in time for

3 hexacyanoferrate(II) and water oxidation at the anode for continuous operation. Anolyte was

4 changed from hexacyanoferrate(II) to water on day 83, as indicated by the dashed line. Anolyte was

5 refreshed on day 115, as indicated by the solid line.

7 In case of hexacyanoferrate(II) oxidation, the cathode resistance was at least $0.43 \Omega \cdot \mathrm{m}^{2}$ (start Fe).

8 Immediately after switching anolyte hexacyanoferrate(II) for water, both the cathode and anode

9 contributed most to total internal resistance (Figure 3). Cathode resistance was at least $1.04 \Omega \cdot \mathrm{m}^{2}$

10 (end water), while anode resistance was at least $1.33 \Omega \cdot \mathrm{m}^{2}$ (start water). The sudden increase in

11 anode resistance after switching anolytes could be attributed to the poor catalytic properties of

12 graphite for water oxidation [26]. The increase in anode and cathode resistances with time may be

13 caused by increasing product concentrations $\left(\mathrm{O}_{2}\right.$, methane, and protons) near or inside the electrode.

14 This could negatively affect reaction kinetics, and gas accumulation inside the electrode could result

15 in less available effective cathode surface area. Transport \& ionic resistances increased with time

16 from $0.015 \Omega \cdot \mathrm{m}^{2}$ (start water) to $0.83 \Omega \cdot \mathrm{m}^{2}$ (end water), despite refreshing the anolyte (day 115 ). In 
this same time period, anolyte conductivity increased from $0.3 \mathrm{~S} / \mathrm{m}$ (start water) to $0.7 \mathrm{~S} / \mathrm{m}$ (end water), while catholyte conductivity decreased from $2.1 \mathrm{~S} / \mathrm{m}$ (start water) to $1.0 \mathrm{~S} / \mathrm{m}$ (end water).

3 This is equal to a decrease in ionic resistance from $0.01 \Omega \cdot \mathrm{m}^{2}$ (start water) to $0.006 \Omega \cdot \mathrm{m}^{2}$ (end

4 water), using the equation described by Sleutels et al. [18] and assuming the distance between the

5 electrodes and the membrane is $5 \mathrm{~mm}$. These calculations show that the transport \& ionic resistance

6 mainly consists of transport losses, and not so much of ionic losses due to limited conductivity of the

7 electrolyte, which is in line with Sleutels et al. [18]. The resistance due to the development of a pH-

8 gradient over the membrane increased in the same time period from $0.17 \Omega \cdot \mathrm{m}^{2}$ (start water) to 0.94

$9 \Omega \cdot \mathrm{m}^{2}$ (end water), with the most prominent increase at the end using water oxidation, as the anolyte

10 acidified due to proton production from pH 6.25 (start water; cathode $\mathrm{pH} 7.09$ ) to 3.37 (end water;

11 cathode $\mathrm{pH}$ 7.10). At the end using water oxidation, all resistances contributed to a similar extent to

12 the total internal resistance.

Increased methane yield per hectare of land area

15 At this point, the methane producing MEC is still in its early stage of development. For an estimation of the potential of a methane producing MEC, two crucial inputs need to be considered:

17 renewable electrical energy and $\mathrm{CO}_{2}$. There are several possible sources and technologies for 18 renewable electricity production: PV cells using solar energy, wind turbines using wind energy, or 19 reverse electrodialysis using the energy from mixing salt and fresh water [27]. A suitable source of $20 \mathrm{CO}_{2}$ should (i) be of renewable origin to be independent of fossil fuels, and (ii) contain high 21 concentrations of $\mathrm{CO}_{2}$, preferably without oxygen present. Gas streams of fermentation processes 22 (renewable fuel production technologies) are therefore an attractive $\mathrm{CO}_{2}$ source for methane 23 producing MECs. As an example, we will discuss biogas produced via anaerobic digestion of 24 biomass. Biogas consists of both $\mathrm{CH}_{4}$ and $\mathrm{CO}_{2}$, which are produced in a 1:1 ratio. To add a higher 25 energetic and economic value to the biogas, it needs to be upgraded, which means that the $\mathrm{CO}_{2}$ 26 content needs to be lowered, and the methane content needs to be increased. Conventionally, $\mathrm{CO}_{2}$ is 27 removed by scrubbing the $\mathrm{CO}_{2}$-rich gas with an aqueous solution containing chemicals (hydroxide, 
amines, etc.) [28]. By contrast, a methane producing MEC does not only lower the $\mathrm{CO}_{2}$ content of

2 biogas, but furthermore, converts $\mathrm{CO}_{2}$ into additional methane. As roughly half of the biogas

3 consists of $\mathrm{CO}_{2}$, the methane yield from anaerobic digestion could be doubled using a methane 4 producing MEC.

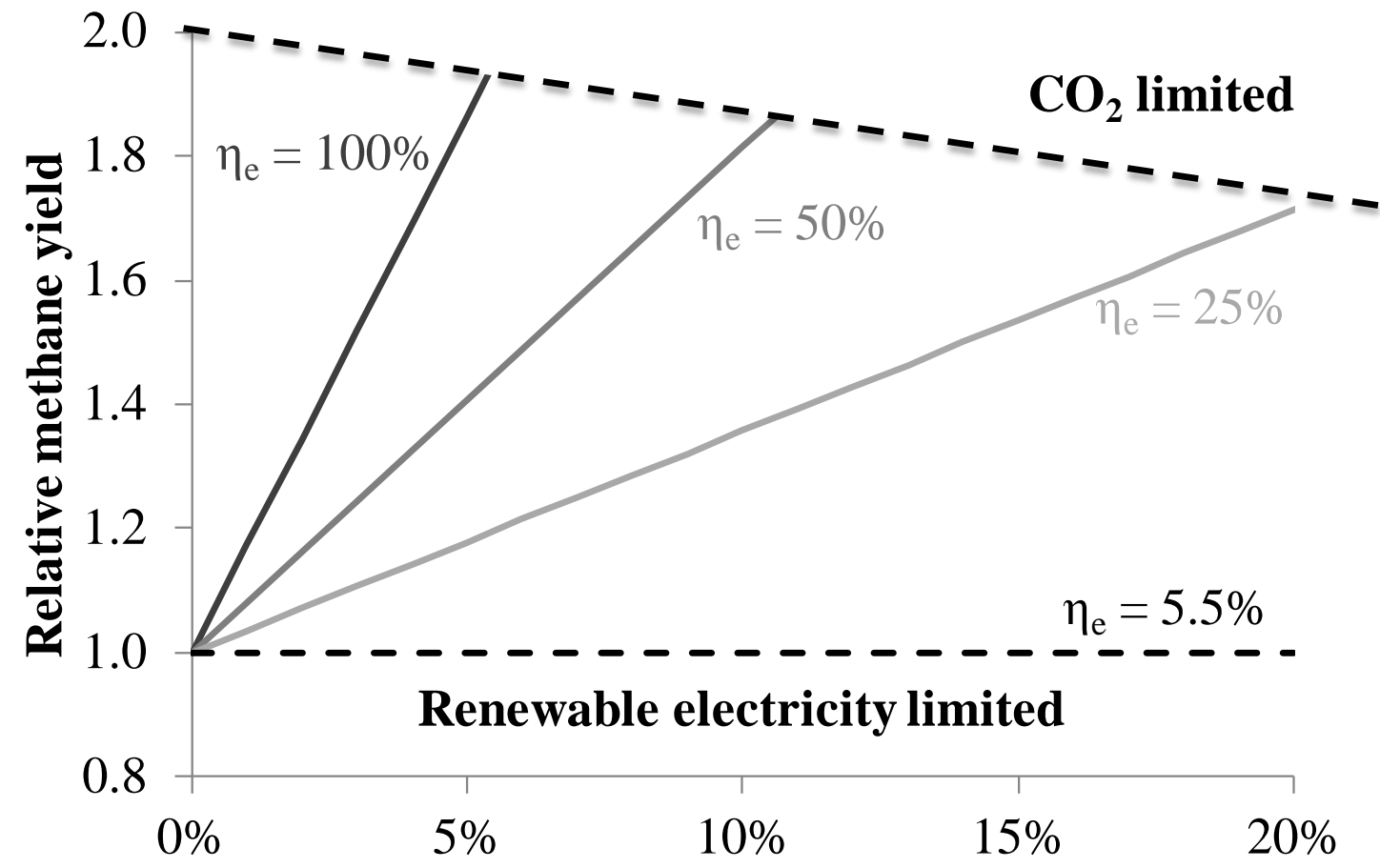

Figure 4. Combining anaerobic digestion and methane producing MECs leads to an improved methane yield per hectare of land area. The energy efficiency $\left(\eta_{\mathrm{e}}\right)$ of the methane producing MEC is

9 calculated as the ratio between the thermodynamic energy input based on the Gibb's free energy of 10 the reaction (9.8 $\mathrm{kWh} / \mathrm{m}^{3}$ methane) divided by the actual electrical energy input. A relative methane 11 yield $>1$ indicates that more methane is produced than via anaerobic digestion alone. Thus, at an 12 energy efficiency above 5.5\%, the combination of anaerobic digestion and methane producing MECs 13 leads to an increased methane yield per hectare of land per year compared to anaerobic digestion.

Figure 4 shows the relative methane yield per hectare of land area per year for combined anaerobic digestion and methane producing MECs using electricity from PV cells. A relative methane yield $>1$

17 indicates that more methane is produced via the combined processes compared to anaerobic 18 digestion alone. The relative methane yield is shown as a function of the surface area used for PV 
1 cells in combination with a methane producing MEC, and the energy efficiency of a methane

2 producing MEC. We assume that PV cells convert the incoming solar radiation of $150 \mathrm{~W} / \mathrm{m}^{2}$ [29]

3 into electricity at an efficiency of 10\% [30], and that biogas consists of equal parts of methane and

$4 \mathrm{CO}_{2}$. In the hypothetical situation of $100 \%$ energy efficiency, which means that no energy losses

5 occur in the MEC system and the energy input consists only of the reversible thermodynamic energy

6 input, to double the methane yield, $5 \%$ of the land area needs to be covered with PV cells in

7 combination with methane producing MECs (meaning that 95\% of the surface area is used for

8 biomass growth, resulting in a lower $\mathrm{CO}_{2}$ yield per hectare, and a relative methane yield $<2$ ). The

9 methane producing MEC should have an energy efficiency higher than 5.5\% to increase methane

10 yield per hectare of land area compared to anaerobic digestion alone (Figure 4).

11 It is important to note that the use of water oxidation at the anode is essential for reaching an

12 additional methane yield compared to existing biomass conversion technologies. Methane producing

13 MECs that use biomass in the form of acetate as the electron donor at the anode, and that recycle the

14 produced $\mathrm{CO}_{2}$ from the anode to the cathode, produce the same mix of $\mathrm{CO}_{2}$ and methane as

15 anaerobic digestion. Oxidation of one mole of acetate at the anode results in 8 moles of electrons and

162 moles of $\mathrm{CO}_{2}$, the latter being present in the form of bicarbonate at biologically relevant $\mathrm{pH} 7$ (eq.

17 16). The formed 8 moles of electrons can be used to reduce only one mole of $\mathrm{CO}_{2}$ (or bicarbonate) to

18 methane (eq. 17). The overall reaction in a methane producing MEC using acetate oxidation at the

19 anode is thus limited by the 8 moles of electrons present in one mole of acetate. Overall, 1 mole of

20 acetate results in 1 mole of methane produced at the cathode, and 1 mole of $\mathrm{CO}_{2}$ produced at the

21 anode (eq. 18).

23 Organic matter oxidation at anode [13]:

$24 \mathrm{CH}_{3} \mathrm{COO}^{-}+4 \mathrm{H}_{2} \mathrm{O} \rightarrow 2 \mathrm{HCO}_{3}^{-}+9 \mathrm{H}^{+}+8 \mathrm{e}^{-}$

25 Carbon dioxide reduction at cathode:

$26 \mathrm{HCO}_{3}^{-}+9 \mathrm{H}^{+}+8 \mathrm{e}^{-} \rightarrow \mathrm{CH}_{4}+3 \mathrm{H}_{2} \mathrm{O}$

27 Overall reaction methane producing MEC using organic matter oxidation at the anode: 
3 In contrast, when using water oxidation at the anode, the amount of electrons is in principle

4 unlimited, meaning that sufficient electrons can be produced to reduce all the $\mathrm{CO}_{2}$ present into

5 methane, leading to a theoretically double methane yield. Methane producing MECs that use an

6 electron source other than biomass are therefore the only way to achieve higher methane yields per

7 hectare of land area compared to anaerobic digestion.

$9 \quad$ Perspectives

10 This study showed that an MEC is suitable to convert $\mathrm{CO}_{2}$ to methane, with a biocathode that

11 continuously converted $\mathrm{CO}_{2}$ to methane for 188 days. The maximum achieved energy efficiency in

12 this study was 51.3\%, obtained during the yield test using water oxidation. An energy efficiency of

$1351.3 \%$ would increase the methane yield per hectare of land area by a factor 1.8 when covering $10 \%$

14 of the land area with PV cells (Figure 4). For these calculations, it is assumed that the methane

15 production rate of methane producing MECs is the same as the $\mathrm{CO}_{2}$ production rate of anaerobic

16 digestion $\left(5 \mathrm{~m}^{3} / \mathrm{m}^{3}\right.$ per day), whereas the maximum achieved methane production rate in this study

17 was still a factor 25 lower. A considerable reduction in internal resistance is still needed to reach

18 sufficiently high conversion rates. The internal resistance analysis shows that several improvements

19 can be made to reduce the internal resistance and to increase energy efficiency. First, high-surface

20 electrode materials with good catalytic properties for water oxidation and with good properties for

21 biofilm development [19] for catalysis of $\mathrm{CO}_{2}$ reduction should be used to decrease cathode and

22 anode losses [13]. Second, by directing the flow through the porous electrode, the surface area can

23 be effectively used and mass transfer losses are decreased [13, 31]. Third, decreasing the distances

24 between membrane and electrodes minimizes mass transfer losses even further [13, 32]. Finally, to

25 increase the coulombic efficiency and the methane content of the gas, a membrane that is less

26 permeable for gases should be used. Implementing these improvements will bring a methane 
producing MEC closer to its potential for increasing the methane yield land use efficiency, and consequently to increase water, and nutrient efficiency.

ACKNOWLEDGMENT.

This research was funded by the SenterNovem "Energie Onderzoek Subsidie: Nieuw Energie

Onderzoek” program (NEOT05005).

REFERENCES.

1. Hoogwijk M, Faaij A, Broek Rvd, Berndes G, Gielen D, Turkenburg W. Exploration of the ranges of the global potential of biomass for energy. Biomass and Bioenergy 2003; 25: 119-133.

2. Escobar JC, Lora ES, Venturini OJ, Yáñez EE, Castillo EF, Almazan O. Biofuels: Environment, technology and food security. Renewable and Sustainable Energy Reviews 2009; 13: $1275-1287$.

$143 . \quad$ Fargione J, Hill J, Tilman D, Polasky S, Hawthorne P. Land clearing and the biofuel carbon 15 debt. Science 2008; 319: 1235-1238.

4. Nonhebel S. Renewable energy and food supply: will there be enough land? Renewable and Sustainable Energy Reviews 2005; 9: 191-201.

5. Satyanarayana KG, Mariano AB, Vargas JVC. A review onmicroalgae, a versatile source for sustainable energy and materials. International Journal of Energy Research 2011; 35: 291-311.

6. IEA. Key World Energy Statistics; 2009.

21 7. Petrus L, Noordermeer MA. Biomass to biofuels, a chemical perspective. Green Chemistry 22 2006; 8: 861-867.

23 8. Rozendal RA, Jeremiasse AW, Hamelers HVM, Buisman CJN. Hydrogen production with a microbial biocathode. Environmental Science and Technology 2008; 42: 629-634.

25 9. Steinbusch KJJ, Hamelers HVM, Schaap JD, Kampman C, Buisman CJN. 26 Bioelectrochemical ethanol production through mediated acetate reduction by mixed cultures. Environmental Science and Technology 2010; 44: 513-517.

10. Rozendal RA, Leone E, Keller J, Rabaey K. Efficient hydrogen peroxide generation from organic matter in a bioelectrochemical system. Electrochemistry Communications 2009.

11. Cheng S, Xing D, Call DF, Logan BE. Direct biological conversion of electrical current into methane by electromethanogenesis. Environmental Science and Technology 2009; 43: 3953-3958.

12. Hamelers HVM, Sleutels THJA, Jeremiasse AW, Post JW, Strik DPBTB, Rozendal RA. Technological factors affecting BES performance and bottlenecks towards scale up. In: Rabaey, K, Angenent, L, Schröder, U and Keller, J (eds). Bio-electrochemical systems: from extracellular electron transfer to biotechnological applications: IWA, 2009.

13. Logan BE, Hamelers B, Rozendal R, Schröder U, Keller J, Freguia S, Aelterman P, Verstraete W, Rabaey K. Microbial fuel cells: methodology and technology. Environmental Science and Technology 2006; 40: 5181-5192.

14. Villano M, Aulenta F, Ciucci C, Ferri T, Giuliano A, Majone M. Bioelectrochemical reduction of $\mathrm{CO}_{2}$ to $\mathrm{CH}_{4}$ via direct and indirect extracellular electron transfer by a hydrogenophilic 
15. Logan BE, Call D, Cheng S, Hamelers HVM, Sleutels THJA, Jeremiasse AW, Rozendal RA. Microbial electrolysis cells for high yield hydrogen gas production from organic matter. Environmental Science and Technology 2008; 42: 8630-8640.

16. Kim JR, Cheng S, Oh S-E, Logan BE. Power generation using different cation, anion, and ultrafiltration membranes in microbial fuel cells. Environmental Science and Technology 2007; 41: 1004-1009.

17. Garcia J-L, Patel BKC, Ollivier B. Taxonomic, phylogenetic, and ecological diversity of methanogenic Archaea. Anaerobe 2000; 6: 205-226.

18. Sleutels THJA, Hamelers HVM, Rozendal RA, Buisman CJN. Ion transport resistance in Microbial Electrolysis Cells with anion and cation exchange membranes. International Journal of Hydrogen Energy 2009; 34: 3612-3620.

19. Heijne At, Hamelers HVM, Saakes M, Buisman CJN. Performance of non-porous graphite and titanium-based anodes in microbial fuel cells. Electrochimica Acta 2008; 53: 5697-5703.

20. Steinbusch KJJ, Hamelers HVM, Buisman CJN. Alcohol production through volatile fatty acids reduction with hydrogen as electron donor by mixed cultures. Water Research 2008; 42: 40594066.

21. Rozendal RA, Hamelers HVM, Molenkamp RJ, Buisman CJN. Performance of single chamber biocatalyzed electrolysis with different types of ion exchange membranes. Water Research 2007; 41: 1984-1994.

22. Rader GK, Logan BE. Multi-electrode continuous flow microbial electrolysis cell for biogas production from acetate. International Journal of Hydrogen Energy 2010; 35: 8848-8854.

23. Clauwaert P, Verstraete W. Methanogenesis in membraneless microbial electrolysis cells. Applied Microbiology and Biotechnology 2009; 82: 829-836.

24. Freguia S, Rabaey K, Yuan Z, Keller J. Electron and carbon balances in Microbial Fuel Cells reveal temporary bacterial storage behavior during electricity generation. Environmental Science and Technology 2007; 41: 2915-2921.

25. Rozendal RA, Hamelers HVM, Euverink GJW, Metz SJ, Buisman CJN. Principle and perspectives of hydrogen production through biocatalyzed electrolysis. International Journal of Hydrogen Energy 2006; 31: 1632-1640.

26. Bonakdarpour A, Esau D, Cheng H, Wang A, Gyenge E, Wilkinson DP. Preparation and electrochemical studies of metal-carbon composite catalysts for small-scale electrosynthesis of $\mathrm{H}_{2} \mathrm{O}_{2}$. Electrochimica Acta 2011; 56: 9074-9081.

27. Post JW, Hamelers HVM, Buisman CJN. Energy recovery from controlled mixing salt and fresh water with a reverse electrodialysis system. Environmental Science and Technology 2008; 42: 5785-5790.

28. Thambimuthu K, Soltanieh M, Abanades JC. Capture of CO2; 2005.

29. Strik DPBTB, Hamelers HVM, Snel JFH, Buisman CJN. Green electricity production with living plants and bacteria in a fuel cell. International Journal of Energy Research 2008; 32: 870-876. 30. Kazmerski LL. Solar photovoltaics R\&D at the tipping point: A 2005 technology overview. Journal of Electron Spectroscopy and Related Phenomena 2006; 150: 105-135.

31. Sleutels THJA, Lodder R, Hamelers HVM, Buisman CJN. Improved performance of porous bio-anodes in microbial electrolysis cells by enhancing mass and charge transport. International Journal of Hydrogen Energy 2009.

32. Chaudhuri SK, Lovley DR. Electricity generation by direct oxidation of glucose in mediatorless microbial fuel cells. Nature Biotechnology 2003; 21: 1229-1232. 
Table 1. Performance of a methane producing biocathode with hexacyanoferrate(II) or water oxidation at the anode during continuous operation and for yield tests.

\begin{tabular}{|c|c|c|c|c|c|c|}
\hline \multirow[b]{3}{*}{ Operation period } & \multicolumn{3}{|c|}{ Hexacyanoferrate(II) oxidation } & \multicolumn{3}{|c|}{ Water oxidation } \\
\hline & \multicolumn{2}{|c|}{ Continuous } & \multirow{2}{*}{$\begin{array}{c}\text { Yield test } \\
\text { Day } 70\end{array}$} & \multicolumn{2}{|c|}{ Continuous } & \multirow{2}{*}{$\begin{array}{l}\text { Yield test } \\
\text { Day } 101\end{array}$} \\
\hline & Start Fe & Middle Fe & & $\begin{array}{l}\text { Middle } \\
\text { water }\end{array}$ & $\begin{array}{c}\text { End } \\
\text { water }\end{array}$ & \\
\hline$E_{\text {cat }}(V)$ & -0.69 & -0.71 & -0.69 & -0.55 & -0.55 & -0.70 \\
\hline$j\left(A / m^{2}\right)$ & 0.87 & 0.80 & 1.09 & 0.25 & 0.21 & 1.75 \\
\hline$r_{\mathrm{CH} 4}\left(\mathrm{~m}^{3} / \mathrm{m}^{3}\right.$ per day $)$ & 0.071 & 0.033 & 0.15 & 0.005 & 0.006 & 0.21 \\
\hline$\eta_{\text {coulombic }}(\%)$ & 64.9 & 33.2 & 104.6 & 17.5 & 23.1 & 95.2 \\
\hline Energy input $\left(\mathrm{kWh} / \mathrm{m}^{3}\right)$ & 15.4 & 31.6 & 16.6 & 97.2 & 73.5 & 18.2 \\
\hline$\eta_{\text {voltage }}(\%)$ & 63.7 & 31.1 & 59.3 & 10.1 & 13.4 & 53.9 \\
\hline$\eta_{\text {energy }}(\%)$ & 42.6 & 10.3 & 62.0 & 1.8 & 3.1 & 51.3 \\
\hline
\end{tabular}

